\title{
KEEFEKTIFAN MODEL PEMBELAJARAN KOOPERATIF TIPE STAD DENGAN PENDEKATAN PROBING-PROMPTING PADA PEMBELAJARAN MATEMATIKA SISWA KELAS X SMA NEGERI 2 POSO
}

\author{
Sertin Allolayuk \\ Universitas Kristen Tentena \\ Email : sertin_allolayuk@yahoo.co.id
}

\begin{abstract}
Abstrak
Jenis penelitian ini adalah penelitian eksperimen dengan randomized two group design, post test only, yang bertujuan untuk : (1) mengetahui bagaimana aktivitas belajar, respon, hasil belajar, tingkat keefektifan siswa selama mengikuti model pembelajaran kooperatif tipe STAD dengan pendekatan probing-prompting, (2) mengetahui bagaimana perbandingan keefektifan penerapan model pembelajaran kooperatif STAD dengan pendekatan probing-prompting dan pembelajaran konvensional, (3) mengetahui apakah ada perbedaan hasil belajar antara siswa setelah diajar dengan menerapkan model pembelajaran kooperatif tipe STAD dengan pendekatan probing-prompting dan model pembelajaran konvensional. Hasil penelitian ini menunjukkan bahwa : (1) siswa sangat aktif, siswa memberikan respon sangat positif ,dalam penerapan model pembelajaran kooperatif tipe STAD dengan pendekatan probing-prompting 84,37\% siswa mencapai kriteria ketuntasan minimal dengan nilai rata-rata 75,63 dari nilai ideal 100 , efektif untuk diterapkan dalam pembelajaran, (2) penerapan model pembelajaran kooperatif tipe STAD dengan pendekatan probing-prompting lebih efektif dibandingkan dengan model pembelajaran konvensional, (3) ada perbedaan hasil belajar antara siswa setelah diajar dengan menerapkan model pembelajaran kooperatif tipe STAD dengan pendekatan probing-prompting dan model pembelajaran konvensional.

Kata Kunci : Keefektifan, STAD, Probing-Prompting
\end{abstract}

\section{PENDAHULUAN}

Matematika merupakan salah satu ilmu dasar yang memegang peranan penting dalam mempercepat penguasaan ilmu pengetahuan dan teknologi, karena matematika merupakan sarana berfikir untuk menumbuh kembangkan cara berpikir logis, sistematis dan kritis. Trigonometri adalah bagian dari matematika. Trigonometri merupakan alat utama ilmu ukur segitiga. Trigonometri memiliki kaitan yang sangat erat dengan kehidupan, baik secara langsung maupun tidak langsung. Pemilihan materi trigonometri dalam penelitian ini dikarenakan trigonometri merupakan materi yang sulit dipahami karena banyaknya rumus yang harus diketahui oleh siswa, ditunjukkan dengan rendahnya nilai ulangan harian siswa pada materi trigonometri yang mengakibatkan rendahnya hasil belajar siswa.

Selain materi trigonometri yang sulit, hasil belajar siswa juga sangat ditentukan oleh kondisi kelas. Berdasarkan hasil observasi, yang terjadi pada pembelajaran matematika di kelas X SMA Negeri 2 Poso yaitu pada umumnya berpusat pada guru, dimana guru lebih memfokuskan diri pada upaya pemindahan pengetahuan ke dalam 


\section{Sertin Allolayuk}

pikiran siswa tanpa memperhatikan bahwa ketika siswa memasuki kelas siswa mempunyai bekal dan pengetahuan yang tidak sama, yang mengakibatkan rendahnya hasil belajar. Oleh karena itu diperlukan adanya suatu strategi pembelajaran yang dapat mengaktifkan semua siswa sehingga kegiatan belajar mengajar berpusat kepada siswa.

Pembelajaran kooperatif adalah suatu model pembelajaran yang digunakan untuk mewujudkan kegiatan belajar mengajar yang berpusat pada siswa, terutama untuk mengatasi permasalahan yang ditemukan guru dalam mengaktifkan siswa, yang tidak dapat bekerjasama dengan orang lain, siswa yang agresif dan tidak peduli pada yang lain (Isjoni, 2011:16). Salah satu tipe model pembelajaran kooperatif adalah tipe STAD. Dalam penelitian ini digunakan model pembelajaran kooperatif tipe STAD karena model ini merupakan model yang paling sederhana dan dapat digunakan untuk mengaktifkan siswa dan memaksimalkan hasil pembelajaran.

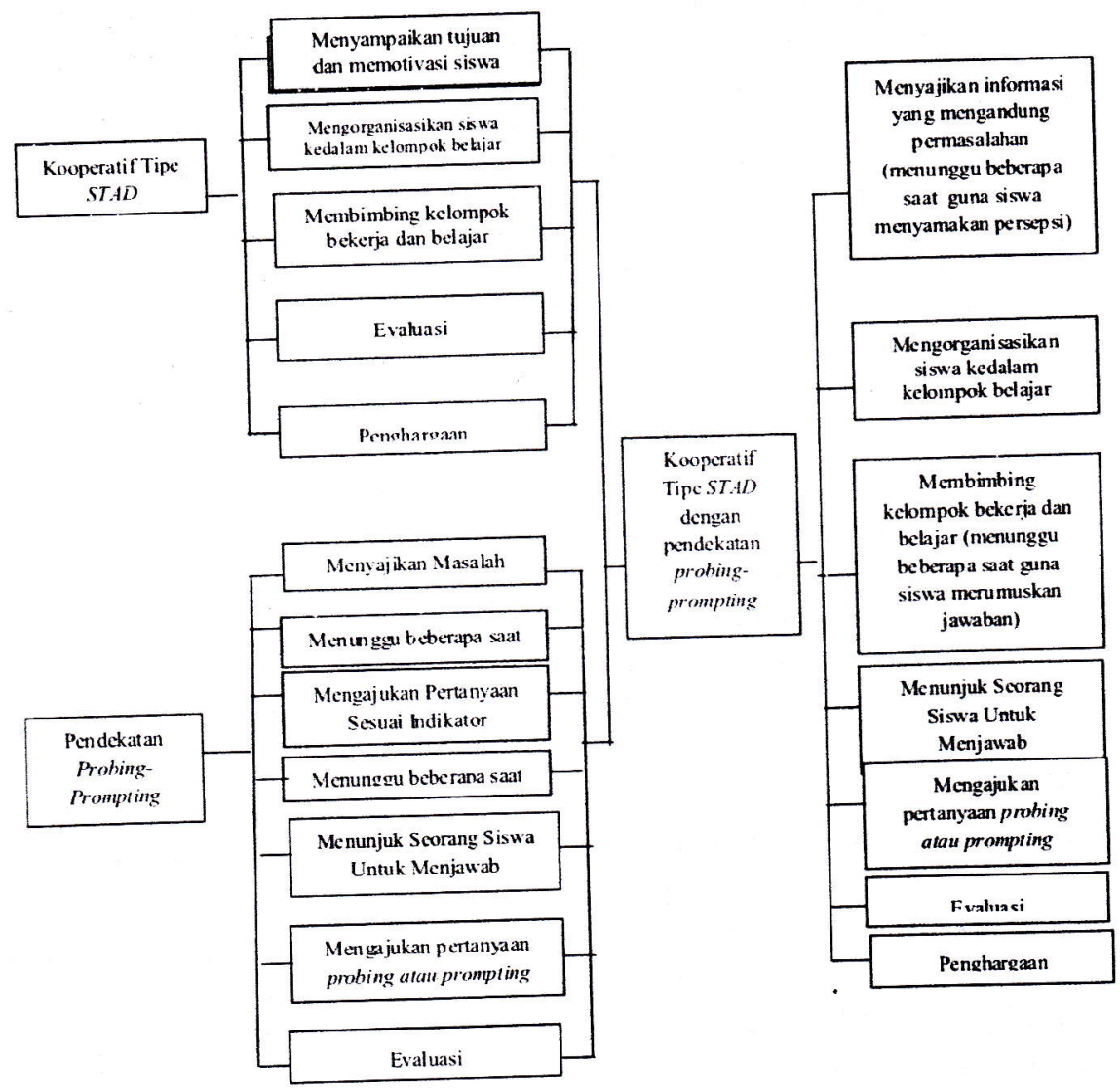
pada gambar di bawah ini:
Selain model pembelajaran, faktor lain yang ikut mempunyai andil dalam menentukan keberhasilan pembelajaran matematika adalah pemilihan pendekatan pembelajaran. Pendekatan probingprompting adalah pendekatan pembelajaran dengan cara guru menyajikan serangkaian pertanyaan yang sifatnya menuntun dan menggali sehingga terjadi proses berfikir yang mengaitkan pengetahuan peserta didik dan pengalamannya dengan pengetahuan baru yang sedang dipelajari (Suherman, 2003).

Menurut Suherman (Rosdiana, 2010), pendekatan probing-prompting adalah pendekatan pembelajaran dengan cara guru menyajikan serangkaian pertanyaan yang sifatnya menggali (probing) dan menuntun (prompting) sehingga terjadi proses berpikir yang mengaitkan pengetahuan siswa dan pengalamannya dengan pengetahuan baru yang sedang dipelajari. Tahapan pembelajaran kooperatif tipe STAD dengan pendekatan probing-prompting dapat dilihat 


\section{METODE}

Jenis penelitian ini adalah penelitian eksperimen dengan desain penelitian Randomized Two Group Design, Post Test Only dan asumsi bahwa tidak ada perbedaan yang signifikan antara kemampuan awal kedua kelas eksperimen.

\begin{tabular}{cccc}
\hline & Kelompok & Perlakuan & Tes Hasil Belajar \\
\hline $\mathrm{R}$ & $O_{1}$ & $\mathrm{~T}$ & $0_{3}$ \\
\hline$O_{2}$ & & $0_{4}$ \\
\hline
\end{tabular}

Keterangan $: \mathrm{R}=$ Random

O_1 = Kelas eksperimen

$\mathrm{O} 2$ = Kelas kontrol

O_3 = Hasil belajar kelas eksperimen

$\mathrm{O} 4$ = Hasil belajar kelas kontrol

$\mathrm{T}^{-}=$Perlakuan pada kelas eksperimen

Populasi dalam penelitian ini adalah seluruh siswa kelas X SMA Negeri 2 Poso tahun ajaran 2014/2015 yang terdiri dari 6 kelas. Penentuan sampel (kelas eksperimen) dalam penelitian ini dilakukan secara acak (cluster random sampling) yaitu kelas X-2 dan X-4. Instrumen yang digunakan dalam penelitian ini terdiri dari lembar validasi ahli, lembar observasi aktivitas siswa, angket respon siswa dan tes hasil belajar.

Teknis analisis data dalam penelitian ini terdiri atas analisis deskriptif dan analisis inferensial.

\section{Analisis Deskriptif}

Untuk menentukan pengkategorian aktivitas siswa dan respon siswa berdasarkan kategori jenjang ordinal (Azwar, 2004:147)

Aktivitas siswa

Kriteria penentuan aktivitas siswa

$$
\mathrm{AS}<2,5 \quad \text { tidak aktif }
$$

$2,5 \triangle \mathrm{AS}<3,5$ aktif

$$
3,5 \triangle \mathrm{AS} \quad \text { sangat aktif }
$$

Kriteria yang digunakan untuk memutuskan aktifitas siswa efektif jika nilai skor ratarata minimal berada dalam kategori aktif $(2,5$ $\triangle \mathrm{AS}<3,5$ ).

Respon siswa

Kriteria untuk respon siswa

$\mathrm{RS}<2,5 \quad$ tidak positif

\section{$2,5 \leqslant \mathrm{R}<3,5$ positif}

$3,5 \$$ S sangat positif

Kriteria yang digunakan untuk memutuskan respon siswa efektif jika nilai skor rata-rata minimal berada dalam kategori positif $(2,5 \triangle A S<3,5)$.

\section{Hasil Belajar Siswa}

Kriteria yang digunakan untuk menentukan kategori hasil belajar matematika siswa mengacu pada Nurkancana (Nilasari : 2013) adalah sebagai berikut :
90 - 100 Sangat tinggi
$80-89 \quad$ Tinggi
$65-79 \quad$ Sedang
55-64 Rendah
0-54 Sangat rendah

Siswa dinyatakan tuntas belajar apabila rata-rata penilaian semua indikator yang diukur minimal sebesar 70. Ketuntasan klasikal dapat tercapai jika $75 \%$ siswa telah mencapai KKM.

Keefektifan pembelajaran

Untuk menentukan tingkat keefektifan dari setiap pembelajaran digunakan kategori sebagai berikut:

\begin{tabular}{|cc|}
\hline Syarai & Kạtégori \\
\hline $3 T$ & Sangat Efektif \\
2TS V T2S & Efektif \\
$3 S$ & Cukup Efektif \\
2TR V TSR V 2SR & Kurang Efektif \\
T2R V S2R V 3R & Tidak Efektif \\
\hline
\end{tabular}

Analisis infer ensial

Analisis inferensial digunakan untuk menguji hipotesis yang diajukan dalam penelitian ini dengan menggunakan program SPSS 20. Jenis uji-t yang digunakan adalah independent sample T-test, dengan kriteria pengambilan keputusan adalah terima $\mathrm{H} 0 \mathrm{jika}$ $\mathrm{p} \geq \mathrm{O}$, QExapi tolak H0 jika taraf taraf signifikansi $\mathrm{p}$ memiliki harga yang lain. 


\section{HASIL PENELITIAN}

Analisis Deskriptif

Hasil Belajar Matematika Siswa

Hasil belajar kelas eksperimen yang diajar dengan model pembelajaran kooperatif tipe STAD dengan pendekatan probing prompting lebih baik daripada kelas kontrol yang diajar dengan model pembelajaran konvensional. Namun kedua kelas telah berada pada kategori sedang berdasarkan rata-raata hasil belajar siswa, namun kelas kontrol belum mencapai KKM sepertiyang ditunjukkan pada tabel berikut:

Tabel 1 Rekapitulasi tes hasil belajar matematika

\begin{tabular}{|c|c|c|c|}
\hline Kelas & & $\begin{array}{c}\text { Kategori } \\
\text { heruntivaln } 1^{\circ} \text {. }\end{array}$ & $\begin{array}{l}\text { Lritesta } \\
\text { hetefethtifari }\end{array}$ \\
\hline Kontrol & 69,84 & 68.75 & Sedang \\
\hline Eksperimen & 75.63 & 84.37 & Sedang \\
\hline
\end{tabular}

Aktivitas Belajar Siswa

Aktivitas siswa pada kelas eksperimen yang diajar dengan model pembelajaran kooperatif tipe STAD dengan pendekatan probing-prompting lebih baik daripada kelas kontrol yang diajar dengan model pembelajaran konvensional ditampilkan pada tabel berikut :

Tabel 2

Rekapitulasi aktivitas siswa

\begin{tabular}{|cccc|}
\hline Kelas & $\begin{array}{c}\text { Shor ludehs, } \\
\text { Kata-kata }\end{array}$ & Kategmi & $\begin{array}{c}\text { Kriteria } \\
\text { Ketiktifan }\end{array}$ \\
\hline Kontrol & 3,14 & Aktif & Sedang \\
\hline Eksperimen & 3,52 & Aktif & Tinggi \\
\hline
\end{tabular}

\section{Respon Siswa}

Model pembelajaran konvensional berada pada kategori positif sedangkan kelas eksperimen yang diajar dengan model pembelajaran kooperatif tipe STAD dengan pendekatan probing-prompting berada pada kategori sangat positif, ditampilkan pada tabel berikut :
Tabel 3

Rekapitulasi Respon Siswa

\begin{tabular}{|c|c|c|c|}
\hline Kat & & $\because$ & 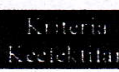 \\
\hline Kontrol & 3,44 & Positif & Sedang \\
\hline Eksperimen & 3,64 & Sangat Positif & Tinggi \\
\hline
\end{tabular}

Keefektifan Pembelajaran

Model pembelajaran konvensional cukup efektif untuk diterapkan dalam pembelajaran, sedangkan model pembelajaran kooperatif tipe STAD dengan pendekatan probing-prompting efektif untuk diterapkan dalam pembelajaran pada materi trigonometri kelas X SMA Negeri 2 Poso, ditampilkan pada tabel berikut :

\section{Tabel 4}

Ketercapaian kriteria keefektifan pembelajaran

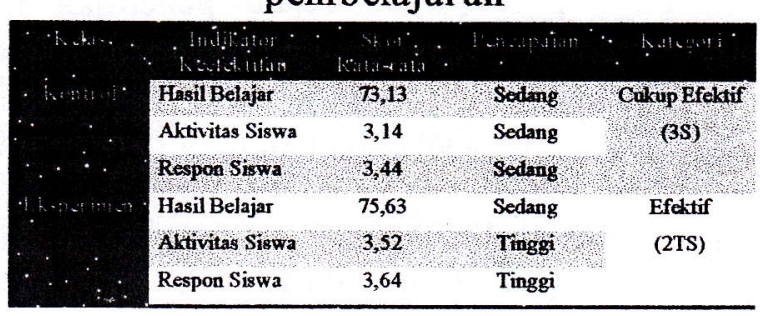

Hasil uji hipotesis dengan Independent Samples T Test, diperoleh nilai probabilitas 0,02 . Oleh karena nilai probabilitas $<a$ $=\mathrm{O}$, $\mathrm{H}$ 0 ditolak atau H1 diterima yang berarti ada perbedaan hasil belajar matematika antara siswa yang telah diajar melalui penerapan model pembelajaran kooperatif tipe STAD dengan pendekatan probing-prompting dan siswa yang telah diajar melalui model pembelajaran konvensional.

\section{PEMBAHASAN}

Berdasarkan kriteria ketuntasan minimal (KKM) yang berlaku di SMA Negeri 2 Poso, tingkat ketuntasan yang dicapai pada penerapan model pembelajaran kooperatif tipe STAD dengan pendekatan probingprompting adalah $84,37 \%$ dan untuk model pembelajaran konvensional adalah $68,75 \%$ dengan materi ajar trogonometri. Kemudian untuk aktivitas siswa selama proses pembelajaran berlangsung baik pada pene- 
rapan model pembelajaran kooperatif tipe STAD dengan pendekatan probingprompting maupun pembelajaran konvensional berada pada kategori aktif. Demikian pula dengan respon siswa, rata-rata memberikan respon positif terhadap penerapan model pembelajaran konvensional dan respon sangat positif terhadap penerapan model pembelajaran kooperatif tipe STAD dengan pendekatan probing-prompting.

Secara statistik inferensial terdapat perbedaan hasil belajar diantara keduanya, demikian halnya secara deskriptif penerapan model pembelajaran kooperatif tipe STAD dengan pendekatan probing-prompting lebih efektif dibandingkan dengan penerapan model pembelajaran konvensional. Hal ini disebabkan karena pada kelas eksperimen siswa dibimbing untuk menjawab pertanyaan sesuai arahan dari guru serta siswa sering dilatih untuk menjawab pertanyaan (umpan balik).

Sejalan dengan pendapat Nur (Trianto, 2009:13) tentang teori yang mendukung ketercapaian keefektifan pembelajaran antara lain teori belajar kontruktivisme, teori perkembangan kognitif Piaget, metode pengajaran John Dewey, teori belajar bermakna David Ausubel, teori penemuan terbimbing Jerome Bruner dan teori pembelajaran sosial Vygotsky.

\section{KESIMPULAN}

Berdasarkan hasil penelitian dan pembahasan, maka kesimpulan dalam penelitian ini adalah: (1) Rata-rata hasil belajar matematika siswa setelah diajar menggunakan model pembelajaran kooperatif tipe STAD dengan pendekatan probing-prompting adalah 75,63 berada pada kategori sedang dengan pencapaian ketuntasan secara klasikal sebesar $84,37 \%$, (2) Siswa aktif mengikuti pembelajaran yang menerapkan model pembelajaran kooperatif tipe STAD dengan pendekatan probing-prompting dengan indeks rata-rata 3,52 atau berada pada kategori Tinggi, (3) $100 \%$ siswa memberikan respon sangat positif terhadap penerapan model pembelajaran kooperatif tipe STAD dengan pendekatan probing-prompting dengan indeks rata-rata 3,64 atau berada pada kategori tinggi, (4) Karena kriteria keefektifan pembelajaran (hasil belajar berada pada kategori sedang, aktivitas dan respon siswa berada pada kategori tinggi) maka model pembelajaran kooperatif tipe STAD dengan pendekatan probing prompting efektif untuk diterapkan dalam pembelajaran pada materi trigonometri kelas $\mathrm{X}$ di SMA Negeri 2 Poso, (5).

Penerapan model pembelajaran kooperatif tipe STAD dengan pendekatan probing-prompting lebih efektif dibandingkan penerapan model pembelajaran konvensional dalam pelaksanaan pembelajaran dengan materi trigonometri kelas X SMA Negeri 2 Poso, (6) Ada perbedaan hasil belajar yang signifikan antara siswa yang telah diajar melalui penerapan model pembelajaran kooperatif tipe STAD dengan pendekatan probing-prompting dengan siswa yang telah diajar melalui penerapan model pembelajaran konvensional.

\section{SARAN}

Berdasarkan hasil penelitian yang telah diperoleh, maka berikut dikemukakan beberapa saran antara lain : (1) Disarankan bagi guru mata pelajaran matematika untuk menerapkan model pembelajaran kooperatif tipe STAD yang melibatkan pendekatan probing-prompting pada pokok bahasan trigonometri, (2) Hasil penelitian ini menunjukkan adanya keefektifan dalam menerapkan model pembelajaran kooperatif tipe STAD yang melibatkan pendekatan probing-prompting , sehingga disarankan untuk menerapkan model pembelajaran ini pada pokok bahasan yang lain agar hasil belajar matematika siswa mencapai hasil yang lebih maksimal, (3) Bagi peneliti yang ingin mengembangkan penelitian ini diharapkan mencermati keterbatasan dalam penelitian ini, sehingga penelitiaan selanjutnya dapat menyempurnakan hasil penelitian ini. 


\section{DAFTAR PUSTAKA}

Aunurrahman. 2012. Belajar dan Pembelajaran. Bandung : Alfabeta.

Firdaus. Efektifitas Pembelajaran Kooperatif Tipe NHT dalam Pembelajaran Matematika di SMA. Tesis tidak diterbitkan. Makassar : PPs UNM.

Hidayat. 2009. Pengetian efektivitas. (http://dansite. Wordpress.com/2009, diakses 27 desember 2012, pukul 23.30 WITA).

Mu'usnadha. 2011. Keefektifan Pembelajaran Kooperatif dengan Penerapan Teori Van Hiele dalam Pembelajaran Geometri di Kelas XI TKJ SMK Negeri 1 Sidendreng. Tesis tidak diterbitkan. Makassar : PPs UNM.

Rosdiana, N. 2010. Penggunaan teknik
Probing-Prompting pada pembelajaran matematika untuk meningkatkan kemampuan pemecahan masalah matematika siswa SMP. Skripsi. Diterbitkan. Jakarta : UPI. (http://repositiry.upi.edu/skripsiview.php?n o skripsi $=5541$, diakses 11 agutus 2011, pükul 10.00 WITA).

Sagala, S. 2008. Konsep dan Makna Pembelajaran. Jakarta: Alfabeta.

Trianto. 2009. Mendesain Model Pembelajaran Inovatif berorientasi Konstruktivistik. Konsep, Landasan, dan implementasinya. Jakarta : Prestasi Pustaka Publisher.

Trianto. 2012. Mendesain Model Pembelajaran Inovatif-Progresif. Jakarta: Kencana Media Group. 